八十九年度 [ 無電渗流作用下毛細電泳自由溶液中抗體抗原間相互作用之動力學模式 系統]結案報告

計劃主持人 : 台大醫學院光電生物醫學中心 林世明助理教授

計劃編躆：NSC 89-2320-B-002-154-M08

執行期限：88/08/01 89/07/31

執行本年度研究計劃成果已經發表一篇學術論文在美國知名雜誌”Analytical Biochemistry"(S. Lin et al., Analytical Biochemistry 284, 422-426 (2000))並在此篇論文最後 Acknowledgment 裡陳述感謝國科會 Grant NSC 89-2320-B-002-154-M08

因此,擬以此篇論文替代此年度之結案報告 
Notes \& Tips

\title{
Characterization of a Polyclonal Anti-hapten Antibody by Affinity Capillary Electrophoresis
}

\author{
Shiming Lin ${ }^{\text {a*}}$, Jui-Chang Tsai ${ }^{a}$ and Su-Ming Hsu ${ }^{\mathrm{b}}$ \\ ${ }^{a}$ Center for Optoelectronic Biomedicine and ${ }^{b}$ Department of Pathology, \\ National Taiwan University College of Medicine, Taipei, Taiwan
}

*Corresponding author:

Dr Shiming Lin

Center for Optoelectronic Biomedicine,

National Taiwan University College of Medicine,

1-1 Jen-Ai Road, Taipei, 100, Taiwan

(Telephone: +886-2-2394-9125

Facsimile : +886-2-2395-7990

E-mail : shiming@ha.mc.ntu.edu.tw) 
Abbreviations used: ACE, affinity capillary electrophoresis; CE, capillary electrophoresis; pAb, polyclonal antibody; DNP, dinitrophenol.

\section{Abstract}

We used affinity capillary electrophoresis (ACE) to characterize a heterogeneous population of polyclonal antibody (pAb) specific to a hapten, dinitrophenol (DNP). The binding migrationshift behavior of anti-DNP pAb to DNP in electrophoretic solution was observed and the affinities of subpopulations were studied. At large DNP excess, the pAb gradually split in two peaks and finally separated at saturating DNP-concentrations. The minor peak migrates at constant time and the major peak shifts away from the other with the increasing amount of DNP. This major peak represents a subpopulation of low to moderate affinity and very few or no high affinity antibodies exist in the major subpopulation. This observation was further verified by preincubation of $\mathrm{pAb}$ with saturating concentrations of DNP followed by CE analysis. It was found that the minor peak in fact represents a subpopulation of low affinity antibodies present in the preparation. The applicability of ACE as a useful tool for the analysis of polyclonal antibody population is demonstrated. 
Keywords:

Capillary electrophoresis; Affinity capillary electrophoresis; Polyclonal antibody; Hapten; Affinity

\section{Introduction}

Polyclonal hapten-specific antibodies are known to contain a heterogeneous population of antibodies which vary in concentration and in the strength of their binding to the hapten (i.e. affinity) (1). The problem of antibody heterogeneity and its importance in the elucidation of structure of antibodies has been studied and reviewed by several investigators $(2,3)$. Observation of hapten-specific antibody subpopulations requires the ability to detect and discriminate between the hapten-anti-hapten complex and the free species by some means. A variety of experimental methods have been devised to observe antibody affinity distributions in antigen- 
antibody reactions or to assess the heterogeneity of affinity. Most of these conventionally use radioactive equilibrium dialysis, enzyme immunoassay or a specific immunoadsorbent technique (4-8). Although these methods for the detection of antigen-antibody complexes are technically simple, they tend to be slow and manually intensive.

Based on the fact that capillary electrophoresis (CE) affords the advantage of very low sample consumption, high mass sensitivity, short analysis time and automatic instrumentation, several studies have used affinity capillary electrophoresis (ACE) to study antigen-antibody interaction by a migration-shift type of experiment (9-12) in which the monoclonal antibody preparation employed, at least in theory, contains a single, homogeneous population of antibody molecules specific to a well-defined epitope. However, in many situations the antibody preparation assayed contains a heterogeneous population of antibodies of different affinity for the immunogen. We, therefore, chose a polyclonal antibody (pAb) specific to a hapten, dinitrophenol (DNP), as a model to evaluate the potential of ACE for detecting anti-DNP antibody subpopulations by studying the migration-shift pattern of DNP-pAb complexes.

\section{Materials and Methods}

Chemicals and samples. All chemicals used were of analytical-reagent grade. Doubly distilled water, filtred with a $0.22-\mu \mathrm{m}$ membrane filter, was used for the preparation of solutions 
and all dilutions. An anti-dinitrophenyl (DNP) antiserum (D-9656), developed in rabbit using DNP conjugated to bovine serum albumin (BSA) as the immunogen, was obtained from Sigma (St. Louis, MO, USA).

Purification of polyclonal anti-DNP antibody. Polyclonal anti-DNP antibody (immunoglobulin $G$ ) was purified from rabbit anti-DNP antiserum (Sigma, D-9656) by chromatography on DEAE-cellulose and mixed with specific immunoadsorbent which was prepared by conjugation of bromoacetyl-cellulose with dinitrophenylated (DNP) porcine gammaglobulin to remove all rabbit serum proteins, including immunoglobulins that do not specifically bind to DNP (13). The purity of the product was identified by SDS-polyacrylamide gel electrophoresis and its specificity was proven to be reactive with DNP-BSA and DNP-RSA but not BSA (bovine serum albumin) or RSA (rabbit serum albumin) by immunoelectrophoresis. The purified antibody was subsequently buffer-exchanged with electrophoresis buffer $(65 \mathrm{mM}$ boric acid-15 mM sodium tetraborate buffer, $\mathrm{pH}$ 8.35) by centrifugal filtration through a $\mathrm{Mr} 10$, 000 cut-off concentrator (amicon, catalog No. 4205).

Instrumentation. The following ACE and CE experiments were performed on a Beckman P/ACE System MDQ equipped with an UV absorbance detector. The uncoated fused-silica capillary used through this study was $57 \mathrm{~cm}$ long $(50 \mathrm{~cm}$ to the detector) with $50 \mu \mathrm{m}$ I.D. All experiments were conducted at $22{ }^{\circ} \mathrm{C}$. Detection was performed by measuring UV absorption at $200 \mathrm{~nm}$ and the detector end of the capillary was negatively polarized relative to the injector end. 
P/ACE System MDQ software was used for the data acquisition.

Affinity capillary electrophoresis (ACE). New capillaries were pretreated with $0.1 \mathrm{M} \mathrm{HCL}$ overnight, with $1 \mathrm{M} \mathrm{NaOH}$ for $10 \mathrm{~min}$, then followed by a 10-min rinse with distilled water and a 5-min rinse with electrophoresis buffer $(65 \mathrm{mM}$ boric acid-15 $\mathrm{mM}$ sodium tetraborate buffer, $\mathrm{pH}$ 8.35). The capillary was rinsed for 2 min with $1 \mathrm{M} \mathrm{NaOH}, 2$ min with distilled water and for 2 min with the electrophoresis buffer between injections. The migration-shift type of experiments were carried out by preparing different concentrations of DNP in the inlet electrophoresis buffers with final concentrations ranging from $1.6 \mu \mathrm{M}$ to $1.638 \mathrm{mM}$. The outlet buffers were the electrophoresis buffers without addition of DNP. Polyclonal anti-DNP antibody (1.6 $\mu \mathrm{M}$ binding sites) and $0.1 \mathrm{mM}$ of a noninteracting peptide marker (Met-Arg-Phe-Ala) were injected by pressure for $5 \mathrm{~s}$. The migration times of the antibody peak (peak $a$ shown in Fig. 1) was adjusted to a fixed value of the migration time of the internal marker. The field strength used for the separations was $20 \mathrm{kV}$. Three repetitions of a series of experiments were performed.

Preincubation followed by $C E$. The DNP at saturating concentration $(1.638 \mathrm{mM})$ was mixed with polyclonal anti-DNP antibody (1.6 $\mu \mathrm{M}$ binding sites) in $65 \mathrm{mM}$ boric acid-15 $\mathrm{mM}$ sodium tetraborate buffer, $\mathrm{pH} 8.35$, in a total volume of $60 \mu \mathrm{l}$. After a $16 \mathrm{~h}$ incubation at $22{ }^{\circ} \mathrm{C}$, each mixture in equilibrium was injected into an uncoated fused-silica capillary (57 cm x $50 \mu \mathrm{m}$ I.D.; $50 \mathrm{~cm}$ to the detector) and the peaks observed. Three repetitions of a series of experiments were performed. 


\section{Results and Discussion}

Currently, the study of receptor-ligand interactions by means of ACE can be performed by a migration-shift type of experiment, the basic principle lies in the observation of an altered electrophoretic mobility of the complexed as compared to free species. The migration-shift-based binding studies was initiated with a set of experiments in which the ligands (DNPs) as one of the interative components were added to the electrophoresis buffer and the receptors (anti-DNP pAb) were subsequently injected. Monitoring of this DNP-binding pAb at a UV absorbance of $200 \mathrm{~nm}$ and with $20 \mathrm{kV}$ field strength allows the observation of binding shifts for various concentrations of DNP. Figure 1 shows the electrophoretic behavior of anti-DNP pAb in the absence and the presence of varying amounts of the DNP. In control experiments, the pAb has a migration time of approximately $3.83 \mathrm{~min}$ (Fig. 1B) in $65 \mathrm{mM}$ boric acid-15 mM sodium tetraborate buffer, $\mathrm{pH}$ 8.35, whereas the DNP has a migration time of approximately 6.19 min (Fig. 1A) under the same conditions. The free pAb in the absence of the DNP (Fig. 1B) is negatively charged at the chosen buffer $\mathrm{pH}$, but moves toward the cathode because, at $\mathrm{pH}$ greater than 6 , the electroosmotic flow in capillaries of uncoated fused silica is sufficiently high to ensure that most anions can be transferred to the negative end at alkaline $\mathrm{pH}(14)$. When a 1- to 32-fold concentration of DNP over pAb binding sites $(1.6 \mu \mathrm{M})$ is conducted with this anti-DNP pAb, the DNP-binding pAb 
does not produce any apparent change in the peak shape or the migration time. However, as shown in Fig 1C-F, at large DNP excess (32- to 1024-fold molar excess) the pAb gradually splits in two subpopulations, i.e., peak $a$ and $b$, and the two peaks finally separate from each other at saturating DNP-concentrations (Fig. 1F). The minor peak (a) was observed to migrate at a constant time (approximately 3.76 min after adjustment to a fixed value of the migration time of the internal marker, standard deviations obtained were $0.90,0.88$, and $0.90 \%$ in triplicate analyses, respectively) with increasing amounts of DNP, while, when the concentrations of DNP were increased continuously, the major subpopulation (peak b) gradually shifted away from peak a. This observation can be attributed to the fact that DNP is anionic at this running $\mathrm{pH}(8.35)$, and, the negative charges change the charge on the complex compared to the free $\mathrm{Ab}$, inducing a change in the migration time of the complex compared to the free Ab. However, why would it take $1.638 \mathrm{mM}$ (1024-fold more excess) DNP to saturate the $1.6 \mu \mathrm{M}$ maximum available binding sites if this major subpopulation of pAb (peak b) contained high (pM) affinity binding sites? A tempting conclusion would be that very few or no high $(\mathrm{pM})$ affinity antibodies exist in the subpopulation, but that they are all, in fact, of low $(\mathrm{mM})$ to median $(\mu \mathrm{M})$ affinity.

On the other hand, to further characterize another minor subpopulation of pAb (peak $a$ ), we also analyze the polyclonal antibody samples (pAb) by preincubation with saturating concentrations of DNP followed by capillary electrophoresis (CE) analysis using an uncoated capillary. Figure 2 illustrates the electropherograms of the pAb samples $(1.6 \mu \mathrm{M})$ after 
preincubation with saturating concentration of DNP $(1638.4 \mu \mathrm{M})$ followed by CE analysis using an uncoated capillary (see Materials and Methods section). As a result, a symmetrical peak was observed (Fig. 2C) and there was no noticeable dissociation of the saturating DNP-pAb complex during electrophoresis. Moreover, the saturating DNP-pAb complex (migration time: 3.95 min) exists as a more negative species compared to the free pAb (approximately $3.83 \mathrm{~min}$ ) due to its complexation with the DNP.

Thus, based on the results obtained above from the ACE experiment and preincubation followed by $\mathrm{CE}$ analysis, we propose that the separated peak $a$ shown in Fig. 1F, in fact, represents a subpopulation of low or very low affinity antibodies present in the preparation. In the ACE experiment (Fig. 1), they are able to participate in a dynamic on-off equilibrium throughout the electrophoresis, while the higher affinity antibodies (peak $b$ ) were more strongly bound; however, they (peak $a$ ) did not induce an appreciable migration change of pAb during the run (10 min) even though experiments were conducted in excess of ligand.

In conclusion, a polyclonal anti-hapten antibody preparation is a heterogeneous mixture of different concentrations of antibodies of different affinity. The changes in the peak that appear in the electropherograms thus are composed of contributions from antibodies with different binding kinetics. In this work, ACE has been used for analysis of polyclonal population of anti-hapten antibody. The interaction between a polyclonal antibody and the corresponding hapten is complex as a result of antibody heterogeneity. However, as shown in this study, a binding 
migration-shift pattern of a monovalent ligand (DNP) to a polyclonal antibody (anti-DNP pAb) is obtained and the antibody affinities can be observed. It is found that very few or no high affinity antibodies exist in the preparation but that they are all in fact of low to moderate affinity. In view of the rapidity and the simplicity of $\mathrm{ACE}$ technique for analyzing the heterogeneous population of anti-DNP antibody, ACE should be generally useful for checking the polyclonal antibody subpopulations specific to other haptens.

\section{REFERENCES}

1. Werblin, T. P., and Siskind, G. W. (1972) Immunochem. 9, 987-1001.

2. Singer, S. J. (1964) Immunochem. 1, 15-21.

3. Haber, E. (1968) Ann. Rev. Biochem. 37, 2197-2203.

4. Steward, M. W. (1986) in Handbook of Experimental Immunology, Vol I, Immunochemistry, Chapter 25.1, Blackwell: Oxford.

5. Sciutto, E., Garat, B., Ortega, E., and Larralde, C. (1987) Mol. Immunol. 24, 577-584.

6. Rath, S., Stanley, C. M., and Steward, M. W. J. (1988) Immunol. Meth. 106, 245-253.

7. Bruderer, U., Deusinger, M., Schurch, U., and Lang, A. B. (1992) J. Immunol. Meth. 151, $157-164$.

8. Kim, Y. T., Werblin, T. P., and Siskind, G. W. (1974) Immunochem. 11, 685-690.

9. Heegaard, N. H. H. (1994) J. Chromatogr. A. 680, 405-412. 
10. Lin, S., Hsiao, I.-Y., and Hsu, S.-M. (1997) Anal. Biochem. 254, 9-17.

11. Colton, I. J., Carbeck, J. D., Rao, J., and Whitesides, G. M. (1998) Electrophoresis 19, 367382.

12. Lin, S., Tang, P., and Hsu, S.-M.(1999) Electrophoresis 20, 3388-3395.

13. Mukkur, T. K. S., Szewczuk, M. R., and Schmidt, D. E. (1974) Immunochem. 11, 9-16.

14. Grossman, P. D., and Colburn, J. C. (1992) in Capillary Electrophoresis: Theory and Practice, pp. 22-23, Academic Press: San Diego. 
Figure Legands

FIG. 1. Electropherograms showing the binding migration-shift pattern of anti-DNP pAb to the DNP in ACE. CE apparatus, Beckman P/ACE System MDQ; uncoated capillary, $57 \mathrm{~cm}(50 \mathrm{~cm}$ effective separation length) x $50 \mu \mathrm{m}$ I.D.; sample, a mixture (35 $\mu \mathrm{l})$ of anti-DNP pAb (1.6 $\mu \mathrm{M}$ maximum available binding sites) in $65 \mathrm{mM}$ boric acid- $15 \mathrm{mM}$ sodium tetraborate buffer, $\mathrm{pH}$ 8.35, pressure-injected at $5 \mathrm{~s}$ followed by electrophoresis in the presence of (B) $0 \mathrm{M} \mathrm{DNP,} \mathrm{(C)}$ $51.2 \mu \mathrm{M}$, (D) $102.4 \mu \mathrm{M}$, (E) $819.2 \mu \mathrm{M}$, and (F) $1638.4 \mu \mathrm{M}$ DNP. Absorbance, UV $200 \mathrm{~nm}$; temperature, $22{ }^{\circ} \mathrm{C}$; operating voltage, $20 \mathrm{kV}$. In control experiments, the pAb has a migration time of approximately 3.83 min (Fig. 1B), whereas the DNP has a migration time of 
approximately $6.19 \mathrm{~min}$ (Fig. 1A) under the same conditions. Two vertical lines indicate the migration time for the peak $a$ in $(\mathrm{D}, \mathrm{E}$ and $\mathrm{F})$ and peak $b$ in $(\mathrm{F})$, respectively.

FIG. 2. Electropherograms illustrating an CE analysis of the pAb samples after preincubation with saturating concentration of DNP in an empty electrophoresis buffer. In control experiments, the free pAb (B) had a migration time of approximately $3.83 \mathrm{~min}$ in $65 \mathrm{mM}$ boric acid-15 $\mathrm{mM}$ sodium tetraborate buffer, $\mathrm{pH} 8.35,20 \mathrm{kV}$, whereas the DNP (A) had a migration time of 6.19 min under the same conditions. A constant amount of pAb $(1.6 \mu \mathrm{M}$ maximum available binding sites) was preincubated for $16 \mathrm{~h}$ at $22{ }^{\circ} \mathrm{C}$ with a saturating concentration of DNP (final concentration $1.638 \mathrm{mM}$ ). Subsequently, the mixture was injected for $5 \mathrm{~s}$, analyzed by CE in 65 $\mathrm{mM}$ boric acid-15 mM sodium tetraborate buffer $(\mathrm{pH} 8.35)$, and detected at UV $200 \mathrm{~nm}$ by use of an uncoated fused-silica capillary (57 $\mathrm{cm}$ x $50 \mu \mathrm{m}$ I.D.). Vertical line indicate the migration time for the free $\mathrm{pAb}$ in $(\mathrm{B})$. 